\title{
Manajemen Laba Setelah Perubahan Peringkat Obligasi Perusahaan
}

\author{
Deviana Sijabat ${ }^{1}$ \\ Fakultas Ekonomi dan Bisnis \\ Universitas Udayana, Indonesia. \\ Email: deviana.sijabat888@gmail.com
}

\author{
I Gusti Ayu Eka Damayanthi \\ Fakultas Ekonomi dan Bisnis \\ Universitas Udayana, Indonesia.
}

\begin{abstract}
ABSTRAK
Penelitian ini bertujuan untuk mendapatkan bukti empiris manajemen laba setelah perubahan peringkat obligasi perusahaan. Model Jones modifikasi digunakan untuk mengidentifikasi perusahaan melakukan praktik manajemen laba. Populasi dalam penelitian ini yaitu seluruh obligasi perusahaan nonkeuangan yang menerbitkan obligasi serta yang mengalami upgrade maupun downgrade peringkat obligasi dalam periode 2010-2016. Metode penentuan sampel dalam penelitian ini menggunakan purposive sampling sehingga diperoleh 30 sampel perusahaan yang mengalami upgrade maupun downgrade. Pengujian hipotersis menggunakan uji One Sample $T$ Test. Simpulan penelitian ini adalah perusahaan penerbit obligasi melakukan manajemen laba yang menaikkan laba setelah peringkat obligasi mengalami upgrade maupun downgrade.
\end{abstract}

Kata Kunci : Manajemen Laba, Peringkat Obligasi, Akrual Diskresioner.

\section{Earnings Management After Changes in Company Bond Ratings}

\section{ABSTRACT}

This study aims to obtain empirical evidence of earnings management after changes in corporate bond ratings. The modified Jones model is used to identify companies that practice earnings management. The population in this study is all bonds of nonfinancial companies that issue bonds and those that experience upgrades or downgrades of bond ratings in the period 2010-2016. The method of determining the sample in this study used purposive sampling to obtain 30 samples of companies that experienced upgrades or downgrades. Hypothesis testing uses the One Sample T Test. The conclusion of this study is that the bond issuing company carries out earnings management that increases profits after the bond rating has undergone an upgrade or a downgrade.

Keywords: Earnings Management, Bond Ratings, Discretionary Accruals.

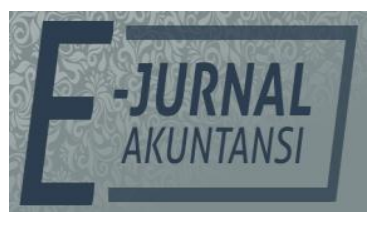

E-JA

e-Jurnal Akuntansi e-ISSN 2302-8556

Denpasar,

Vol. 28 No. 3

September 2019

Hal. 2096-2109

Artikel masuk:

27 Mei 2019

Tanggal diterima: 13 Juni 2019 


\section{PENDAHULUAN}

Bursa Efek Indonesia (BEI) mengartikan obligasi sebagai surat utang jangka menengah panjang yang dapat dipindahtangankan serta berisi janji dari pihak yang menerbitkan untuk membayar imbalan berupa bunga pada periode tertentu dan melunasi pokok utang pada waktu yang telah ditentukan kepada pihak pembeli obligasi tersebut. Sehingga menurut (Mahfudhoh \& Cahyonowati, 2014) menyatakan bahwa obligasi sebagai produk dari pasar modal yang dapat memberikan penghasilan tetap bagi pemegengnya.

Obligasi nampaknya diminati oleh para investor karena menawarkan berbagai keuntungan, diantaranya ketika perusahaan mengalami kebangkrutan maka pemegang obligas akan memiliki hak pertama untuk klaim atas aset perusahaan, investor yang memegang obligasi selain mendapatkan pembayaran pokok atas utang juga akan memperoleh bunga atas utang tersebut, dan pemegang obligas tidak memiliki hak untuk turut andil dalam operasi perusahaan. Akan tetapi tidak dapat dipungkiri bahwa obligas juga memiliki kelemahan, yakni ketika perusahaan yang menerbitkan obligasi tidak mampu untuk membayar ketika telah jatuh tempo. Risiko ini tentunya dapat dihindari sebelum investor memutuskan untuk membeli surat utang tersebut yakni dengan melakukan analisis yang cermat terkait perusahaan yang akan dibeli obligasnya, bagaimana prospek ke depan dan laporan keuangannya.

Perusahaan yang menerbitkan obligasi akan diberikan rating atau peringkat tertentu yang dilihat dari kemampuan perusahaan untuk membayar ketika obligasi tersebut jatuh tempo. Informasi peringkat semacam ini merupakan hal yang patut dipertimbangkan oleh investor sebelum mengambil keputusan terkait obligasi mana yang akan diinvestasikan untuk meminimalkan kemungkinan risiko likuiditas perusahaan. Perbedaan penerimaan informasi antara perusahaan dengan investor dapat diatasi melalui adanya peringkat obligasi ini (Yasa, 2010). Lembaga pemeringkat kredit (selanjutnya dinyatakan CRA) berspesialisasi dalam menganalisis dan mengevaluasi kelayakan kredit dari perusahaan dan penerbit surat berharga efek hutang. Logika yang mendasari keberadaan CRA adalah untuk memecahkan masalah asimetri informatif antara pemberi pinjaman dan peminjam mengenai kelayakan kredit dari yang terakhir (Elkhoury, 2009).

Peringkat kredit, yang dikeluarkan oleh lembaga peringkat adalah penilaian yang tersedia untuk umum tentang apakah instrumen akan dapat melakukan sesuai dengan ketentuan masalah mereka (Payne, 2014). Lembaga pemeringkat obligasi berfungsi sebagai penjaga gerbang untuk pasar keuangan, dan memberikan manfaat nyata bagi regulator pasar keuangan dengan mengurangi biaya regulasi (Rhee, 2015). Lembaga ini diharuskan untuk terus memantau, dan secara berkala meninjau peringkat yang dikeluarkan oleh mereka untuk efek sepanjang masa efek tersebut. Lembaga pemeringkat berkewajiban untuk menyebarkan informasi secara tepat waktu mengenai peringkat yang baru ditugaskan atau perubahan peringkat sebelumnya melalui siaran pers dan situs web (Prakash, et al., 2017). Investor dapat berpatokan pada hasil peringkat yang dikeluarkan oleh lembaga ini untuk memastikan kondisi keuangan perusahaan sebelum mengambil keputusan investasi. 
Peringkat ini diterbitkan oleh lembaga pemeringkat obligasi yang tujuan utamanya adalah untuk menilai dan mempublikasikan kelayakan obligasi dan solvabilitas perusahaan untuk mengurangi asimetri informasi antara peminjam dan pemberi pinjaman. Peringkat tersebut dinilai dengan meninjau risiko bisnis, risiko perusahaan dan risiko keuangan perusahaan. Peringkat obligasi didasarkan pada kinerja masa lalu dan disesuaikan sepanjang tahun. Lembaga pemeringkat mengawasi bagaimana pasar memperlakukan produk keuangan perusahaan tertentu dan melakukan penelitian mendalam untuk merumuskan peringkat mereka. Perusahaan juga dapat mengajukan permohonan peringkat obligasi, misalnya, sebelum penerbitan hutang. Penerbit utang kemudian membahas proses pemeringkatan dan persyaratan informasi dengan lembaga pemeringkat obligasi. Perusahaan dengan peringkat obligasi yang sama harus memiliki biaya hutang yang sama. Ketika peringkat obligasi perusahaan diturunkan (ditingkatkan) biaya hutang perusahaan itu akan meningkat, karena keberisikoan perusahaan akan meningkat dan ini akan memberi sinyal kepada investor. Jadi, dalam hal suku bunga fleksibel, penurunan peringkat obligasi adalah biaya langsung bagi perusahaan ketika mereka mengeluarkan lebih banyak utang.

Otoritas Jasa Keuangan (OJS) memberikan informasi mengenai 2 lembaga pemeringkat domestik yang diakui di Indonesia dan dapat dijadikan acuan bagi para investor, yakni PT. Pemeringkat Efek Indonesia (PEFINDO) dan PT. Fitch Ratings Indonesia. PEFINDO sebagai salah satu lembaga pemeringkat independen yang telah mendapatkan kepercayaan masyarakat luas menyatakan terdapat dua jenis peringkat obligasi. Pertama, investment grade yang terdiri dari perusahaan yang dinilai mampu untuk memenuhi kewajibannya, dan yang kedua non investment grade yang terdiri dari perusahaan yang diragukan dalam pemenuhan kewajibannya (Dewi \& Yasa, 2015). Peringkat obligasi dapat menjadi salah satu dasar investor dalam menentukan keputusan investasi, namun hal ini tidaklah mutlak (Mahfudhoh \& Cahyonowati, 2014). Perusahaan nyatanya dapat mengalami penurunan dalam peringkatnya di lembaga peringkat obligasi karena kemunduran perusahaan (downgrade). Hal ini menyebabkan menurunnya minat investor untuk menanamkan modalnya. Berbanding terbalik dengan perusahaan yang mengalami kemajuan dalam usahanya akan mengalami peningkatan peringkat obligasi (upgrade) oleh lembaga pemeringkat, sehingga keadaan semacam ini menarik kepercayaan masyarakat dan investor.

Fenomena upgrade dan downgrade peringkat obligasi dapat dinilai dari segi keuangan yakni dari laporan keuangan perusahaan, dan segi non keuangan yang dilihat dari jaminan, reputasi auditor, dan lain sebagainya. Partha \& Yasa, (2016) menyatakan dalam penelitiannya bahwa variabel berikut profitabilitas, leverage, solvabilitas dan produktivitas) dapat dijadikan acuan dalam menilai peringkat obligasi perusahaan. Peringkat obligasi yang dikeluarkan oleh lembaga pemeringkat dianggap kurang akurat seperti yang dijelaskan dalam penelitian Parnes \& Akron, (2016). Ederington, et al., (2015) berpendapat bahwa ini bisa terjadi karena perusahaan secara sukarela merilis kabar baik ke pasar tetapi enggan untuk mengeluarkan informasi yang tidak menguntungkan. Ini akan membuat bias terhadap konten informasi negatif untuk perubahan peringkat kredit. Sebagai alternatif, lembaga pemeringkat dapat mengeluarkan lebih 
banyak sumber daya dalam mendeteksi penurunan kualitas kredit daripada perbaikan karena biaya reputasi yang lebih tinggi karena gagal mendeteksi masalah kredit yang menjulang (Jorion \& Zhang, 2009)

Manajer merupakan bagian perusahaan yang mengetahui secara detil informasi perkembangan perusahaan. Manajer memiliki tanggungjawab untuk mengelola perusahaan (Wicaksono, 2015). Manajer diberikan kepercayaan oleh investor untuk mengelola perusahaannya, dan memiliki kewajibannya untuk memberikan laporan mengenai pertumbuhan perusahaan kepada para pemegang saham. Manajer memiliki kesempatan untuk menyalahgunakan kebijaksanaan manajerial mereka untuk meningkatkan atau menurunkan kinerja laba perusahaan dalam jangka pendek. Dengan melakukan ini mereka dapat mencoba mengubah persepsi lembaga pemeringkat kredit tentang kredibilitas perusahaan mereka. Salah satu kemungkinan yang dimiliki manajer adalah mengembang atau mengempiskan akrual saat ini dengan mengalihkan pendapatan dari periode masa depan ke masa sekarang atau dengan menunda pengakuan biaya. Karena investor biasanya mengandalkan pendapatan untuk menilai saham, itu merupakan indikator penting dari kinerja perusahaan. Akibatnya, manajer perusahaan memiliki insentif yang kuat untuk memanipulasi pendapatan mereka untuk mempengaruhi keputusan investor (Bouwens, 2017).

Ge \& Kim, (2014) berpendapat bahwa manajer yang perusahaannya mengalami downgrade melakukan manajemen laba berbasis akrual yang menerapkan kebijaksanaan atas pilihan akrual untuk mencapai tingkat pendapatan yang diinginkan. Akrual muncul ketika ada perbedaan antara waktu arus kas dan waktu pengakuan transaksi pada laporan laba rugi. Manajer memiliki banyak pengaruh atas waktu item pengeluaran aktual, yang memberi mereka kesempatan untuk memiliki banyak keleluasaan dalam menentukan pendapatan aktual yang dilaporkan perusahaan periode tertentu dengan menggunakan akuntansi akrual.

Penelitian ini memiliki tujuan untuk mencari kebenaran terkait manajemen laba yang kemungkinan dilakukan manajer apabila terjadi upgrade maupun downgrade perusahaan, serta membuktikan konsisten maupun tidaknya hasil penelitian yang memiliki model sama namun obyek dan periode penelitian yang berbeda.

Teori sinyal didasarkan pada gagasan bahwa pengguna internal mengetahui lebih banyak hal daripada pengguna eksternal. Apalagi upah dan hak istimewa yang dimiliki manajer terkadang tergantung pada nilai pasar perusahaan (Markopou \& L, 2009). Teori sinyal adalah teori yang dibangun di atas anggapan bahwa manajer memiliki informasi yang unggul daripada para pemangku kepentingan tentang kegiatan perusahaan, dan dalam hal ini manajer dapat meningkatkan komponen leverage. Sinyal yang diberikan oleh perusahaan terdiri atas proyeksi perusahaan di masa yang akan datang dilihat dari kinerja di tahun sebelumnya. Teori sinyal sebenarnya sebagai cara alternatif yang ditempuh manajer untuk menghindari adanya asimetri informasi yang dapat berdampak buruk pada hubungan antara perusahaan dengan para pemegang saham. Peringkat obligasi merupakan salah satu sinyal yang diberikan perusahaan kepada investor. Perusahaan yang lebih banyak memanfaatkan utang memberikan sinyal yang baik karena utang menunjukkan perusahaan 
akan menggunakan utangnya untuk perkembangan perusahaan (Michayluk \& Zhao, 2010).

Teori agensi menjelaskan hubungan yang terjadi antara prinsipal pemilik organisasi dan agen yang menjalankan organisasi. Manajer diharapkan untuk menjalankan perusahaan seefisien mungkin untuk memenuhi pembayaran bunga atas hutang dan memaksimalkan kekayaan pemegang saham. Dengan demikian, teori agensi melindungi hubungan antara pemegang saham, pemegang hutang dan manajemen (Naser, et al., 2015). Informasi yang diterima prinsipal kemudian digunakan sebagai acuan untuk mengambil keputusan. Hal ini menyebabkan manajer sebagai agen terdorong untuk melakukan manipulasi laba yang membuat seolah-olah laba perusahaan tinggi untuk meningkatkan peringkat perusahaan dalam obligasi. Namun tindakan tersebut tidak sematamata untuk keuntungan pribadi manajer, melainkan untuk menjaga kinerja perusahaan.

Manajemen laba mencakup upaya untuk mencapai hasil yang diperkirakan atau laba yang lancar selama periode akuntansi. Ini dapat dilakukan dengan cara yang sah dan kurang sah. Misalnya dengan menunda transaksi hingga periode selanjutnya, atau dengan mempercepat pengeluaran saat penghasilan tinggi dan sebaliknya (Bouwens, 2017).

Manajemen laba adalah pilihan yang dibuat oleh manajer berkenaan dengan kebijakan akuntansi, atau tindakan yang memengaruhi laba, untuk mencapai beberapa tujuan penghasilan tertentu (Scott, 2015), juga menjelaskan beberapa bentuk dalam manajemen laba yakni Taking a Bath cenderung dilakukan oleh manajer ketika perusahaan mengalami penurunan kinerja selama periode berjalan dan biasa terjadi pada periode stress atau reorganisasi. Pada saat terjadi kondisi tersebut, seluruh biaya yang akan dikeluarkan perusahaan pada periode mendatang akan ditambahkan dengan kerugian periode berjalan dengan harpan pada periode mendatang diperoleh keuntungan sesuai dengan harapan bonus. Manajer cenderung menurunkan laba yang dilaporkan untuk menghindari sorotan pemerintah dengan cara menunda pendapatan atau mempercepat biaya (Income Decreasing). Manajer cenderung menaikkan laba yang dilaporkan agar memperoleh bonus yang lebih besar dan cenderung menaikkan laba ketika perusahaan mendekati waktu pelanggaran kontrak utang (Income Increasing). Teknik ini dilakukan oleh manajemen yang memilih untuk meratakan laba dengan melaporkan trend pertumbuhan laba yang stabil dibandingkan perubahan laba yang meningkat/menurun secara drastis (Income smoothing).

Pendapat Sari \& Yasa, (2016) menyatakan bahwa peringkat obligasi merupakan penilaian terkait kondisi dan kemampuan penerbit untuk memenuhi tanggungjawab utangnya. Menurut (Adelson, 2012), peran utama peringkat kredit adalah, untuk membantu menutup kesenjangan informasi antara pemberi pinjaman dan peminjam dengan memberikan pendapat independen tentang kelayakan kredit. Pemegang obligasi dapat menjadikan peringkat obligasi sebagai acuan namun tidak merupakan satu-satunya hal yang dijadikan pertimbangan. Penilaian ini diberikan untuk membantu memberikan gambaran kepada calon pemegang obligasi terkait keadaan perusahaan, dan menunjukkan tingkat risiko dari keputusan yang diambil. 
Obligasi biasanya akan mendapatkan pemeringkatan secara berkala yang dikeluarkan oleh lembaga pemeringkat. Pemeringkatan obligasi tersebut dilakukan untuk memperkirakan kemampuan dari issuer untuk membayar bunga dan pokok utang berdasarkaan analisis keuangan dan kemampuan membayar kredit. Semakin tinggi peringkat obligasi menunjukkan tingginya kemampuan issuer untuk membayar utangnya.

Bondholder perlu memperhatikan peringkat obligasi perusahaan yang menerbitkan obligasi. Peringkat obligasi yang diberikan kepada suatu perusahaan menunjukkan skala resiko dari obligasi yang diperdagangkan serta menunjukkan seberapa aman obligasi bagi bondholder. Keamanan ini dapat dilihat melalui kondisi keuangan perusahaan yang digunakan untuk mengukur kemampuan perusahaan dalam membayar pokok pinjaman beserta bunganya.

PEFINDO sebagai salah satu lembaga pemeringkat obligasi di Indonesia telah banyak berkontribusi dalam menilai kemampuan para penerbit obligasi. Dalam menilai obligasi pefindo memberikan peringkat obligasi sebagai berikut.

\section{Tabel 1. Peringkat Obligasi berdasar PEFINDO}

\begin{tabular}{cl}
\hline Peringkat & \multicolumn{1}{c}{ Keterangan } \\
\hline AAA & $\begin{array}{l}\text { Efek utang yang peringkatnya paling tinggi dan beresiko paling rendah } \\
\text { yang didukung oleh kemampuan obligor yang superior relatif dibanding } \\
\text { entitas Indonesia lainnya untuk memenuhi kewajiban jangka panjangnya } \\
\text { sesuai dengan perjanjian. }\end{array}$ \\
\hline \multirow{2}{*}{ AA } & $\begin{array}{l}\text { Efek utang yang memiliki kualitas kredit sedikit dibawah peringkat } \\
\text { tertinggi, didukung oleh kemampuan obligor yang sangat kuat untuk } \\
\text { memenuhi kewajiban finansial jangka panjangnya sesuai dengan } \\
\text { perjanjian, relatif dibanding dengan entitas Indonesia lainnya. Dan tidak } \\
\text { mudah dipengaruhi oleh perubahan keadaan. }\end{array}$ \\
\hline A & $\begin{array}{l}\text { Efek utang yang beresiko investasi rendah dan memiliki kemampuan } \\
\text { dukungan obligor yang kuat dibanding entitas Indonesia lainnya untuk } \\
\text { memenuhi kewajiban finansialnya sesuai dengan perjanjian namun cukup } \\
\text { peka terhadap perubahan yang merugikan. }\end{array}$ \\
\hline BBB & $\begin{array}{l}\text { Efek utang yang beresiko investasi cukup rendah didukung oleh } \\
\text { kemampuan obligor yang memadai, relatif dibanding entitas Indonesia } \\
\text { lainnya untuk memenuhi kewajiban finansialnya sesuai dengan perjanjian } \\
\text { namun kemampuan tersebut dapat diperlemah oleh perubahan keadaan } \\
\text { bisnis dan perekonomian yang merugikan. }\end{array}$ \\
\hline Efek utang yang menunjukkan dukungan kemampuan obligor yang agak \\
lemah relatif dibanding entitas Indonesia lainnya untuk memenuhi \\
kewajiban finansial jangka panjangnya sesuai dengan perjanjian serta \\
peka terhadap keadaan bisnis dan perekonomian yang tidak menentu dan \\
merugikan.
\end{tabular}

Bersambung ... 
Lanjutan Tabel 1.

\begin{tabular}{cl}
\hline CCC & $\begin{array}{l}\text { Efek utang yang tidak mampu lagi memenuhi kewajiban finansialnya } \\
\text { serta hanya bergantung kepada perbaikan keadaan eksternal. }\end{array}$ \\
\hline D & Efek utang yang macet atau emitennya sudah berhenti berusaha. \\
\hline
\end{tabular}

Sumber: www.PEFINDO.com

PEFINDO sebagai lembaga rating lokal yang banyak memberikan penilaian rating terhadap surat utang berbagai perusahaan di Indonesia, memiliki level rating yang dapat dilihat di tabel 1. Berdasarkan peringkatnya obligasi terbagi menjadi 2 kelompok sebagai berikut: Investment grade bonds: peringkat minimal BBB merupakan obligasi yang layak untuk dijadikan investasi dan memiliki risiko yang tidak terlalu besar. Non investment grade bonds: dengan peringkat CC atau speculative dan D atau junk bond adalah obligasi yang memiliki peringkat di bawah investment grade. Disebut junk karena obligasi ini lebih berisiko dari obligasi yang berkategori investment grade.

PEFINDO memberikan tanda $(+)$ positif untuk obligasi yang memiliki risiko rendah dan memungkinkan adanya upgrade, dan tanda (-) negatif untuk obligasi yang memiliki risiko cukup tinggi yang memungkinkan adanya downgrade.

Fleksibilitas dalam menerapkan prinsip akuntansi memberikan keleluasaan bagi manajer untuk menggunakan metode akuntansi yang dapat menguntungkan perusahaan. Sebagai pihak internal perusahaan, manajer memiliki informasi yang tidak dapat diakses pihak luar. Ketika manajemen memberikan sebuah informasi, maka hal ini akan dianggap sebagai sinyal bagi para investor terkait keadaan perusahaan, sehingga hal ini akan menjadi acuan untuk menanamkan modalnya atau tidak pada perusahaan tertentu (Wahyudi, 2014). Haryono \& Prodi, (2015) menyatakan apabila perusahaan mengalami downgrade maka kemungkinan hal ini memberikan sinyal bahwa perusahaan memiliki kesulitan dalam membayar utang dan sedang mengalami kemunduran bisnis. Hal semacam ini tentu akan direspon negatif bagi masyarakat dan investor yang meragukan kemampuan perusahaan. Situasi tersebut berdampak pada kesulitan perolehan dana yang dialami oleh penerbit obligasi, dan penerbit meresponnya melalui penawaran bunga yang tinggi.

Penurunan peringkat obligasi memberikan informasi risiko gagal bayar tinggi dan cenderung menurunkan tingkat kepercayaan pengambil keputusan investasi. Hal tersebut menyebabkan penerbit kesulitan dalam perolehan dana, maka untuk mendapatkan dana, penerbit memberikan bunga yang tinggi. Hal inilah menyebabkan manajer melakukan manajemen laba ketika terjadi downgrade obligasi dengan maksud memberikan sinyal kepada lembaga pemeringkat bahwa kinerja perusahaan telah membaik sehingga dapat meningkatkan peringkat obligasi.

Peringkat membantu mengurangi masalah yang timbul dari informasi asimetris antara penerbit utang dan investor. Peringkat yang diberikan oleh lembaga-lembaga ini berdampak pada pemangku kepentingan di pasar dalam beberapa cara; penurunan peringkat biasanya memicu kenaikan tingkat bunga penerbit surat utang negara (Cooke \& Bailey, 2015). Ade (2004) menyatakan bahwa manajer akan melakukan manajemen laba ketika perusahan mengalami downgrade dengan cara melalui discretionary accruals positif. Sejalan dengan 
penelitian Pratiwi, \& Werastuti, (2015) yang menunjukkan bahwa perusahaan downgrade akan melakukan manajemen laba yaitu dengan meningkatkan laba yang diperoleh.

Peringkat obligasi dapat memberikan informasi tentang kualitas perusahaan di luar informasi lain yang tersedia untuk umum. Lembaga pemeringkat dapat menerima informasi perusahaan penting yang tidak publik. Misalnya, perusahaan mungkin enggan untuk memberikan informasi kepada pasar yang akan membahayakan program strategis mereka, khususnya yang berkaitan dengan pesaing. Agen kredit mungkin juga berspesialisasi dalam pengumpulan informasi dan proses evaluasi dan dengan demikian memberikan ukuran peringkat kredit perusahaan yang lebih andal (Shin, et al., 2012).

Manajemen laba memberikan pengaruh positif pada peringkat obligasi. Perusahaan dengan peringkat downgrade akan melakukan manajemen laba yang meningkatkan laba dengan harapan dapat meningkatkan tingkat kemampuan membayar utang mereka. Praktik ini dilakukan manajemen untuk menyelamatkan perusahaan agar memperoleh pinjaman dana dari investor dan berupaya untuk menarik kepercayaan investor untuk menanamkan modalnya. Manajer melakukan manajemen laba untuk memberikan informasi positif kepada agen pemberi peringkat obligasi sehingga hal ini akan berdampak pada diperolehnya peringkat obligasi yang terbaik (Andriyani \& Darmawati, 2016).

Sesuai uraian tersebut dapat ditarik hipotesis sebagai berikut.

$\mathrm{H}_{1}$ : Perusahaan melakukan manajemen laba setelah peringkat obligasi mengalami downgrade dan upgrade dengan menaikkan laba.

Berikut kerangka konseptual untuk hubungan logis dari landasan teori dan kajian empiris, sebagai berikut.

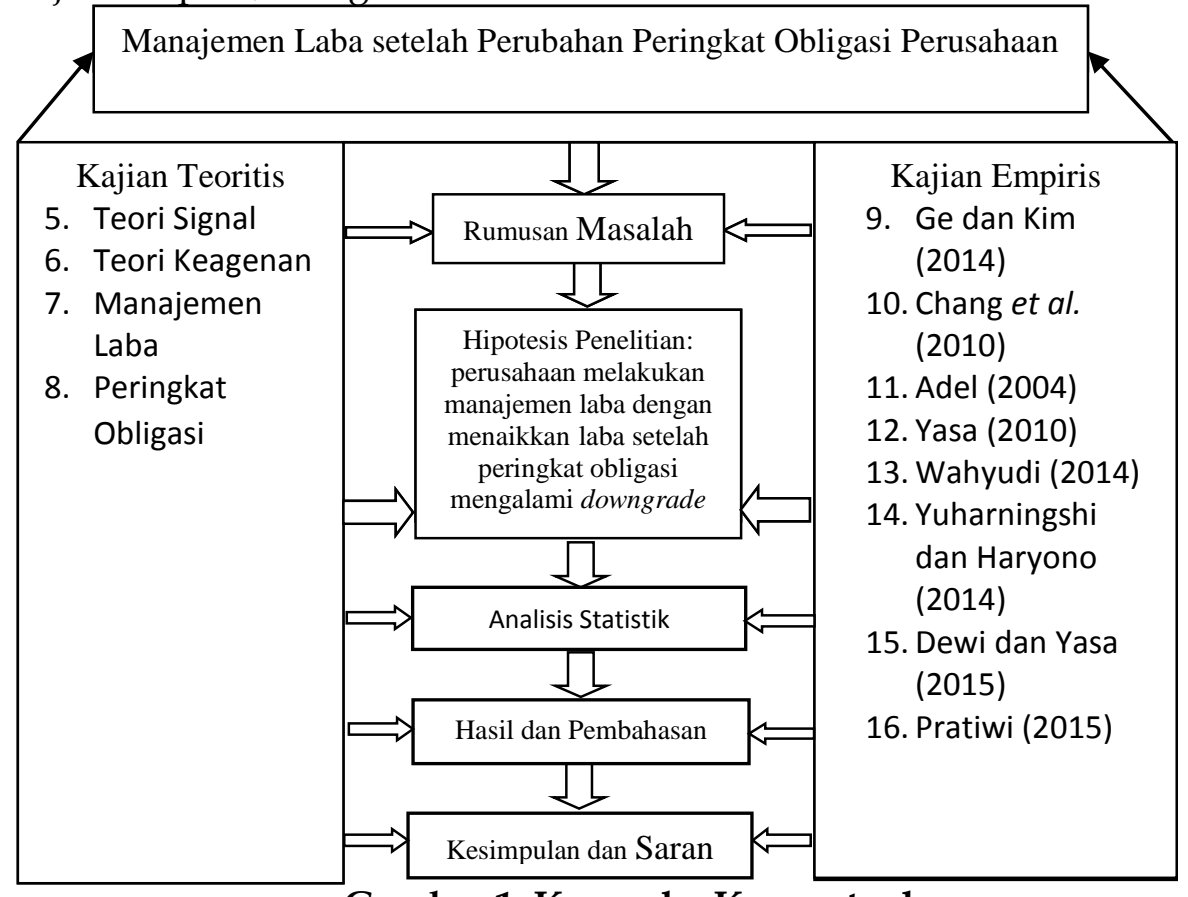

Sumber: Data Penelitian, 2019

Gambar 1. Kerangka Konseptual 


\section{METODE PENELITIAN}

Penelitian ini memfokuskan pada perilaku praktik manajemen laba yang dilakukan manajer sebagai dampak dari adanya peningkatan atau penurunan peringkat obligasi perusahaan. Gambaran penelitian disajikan sistematis seperti gambar berikut.
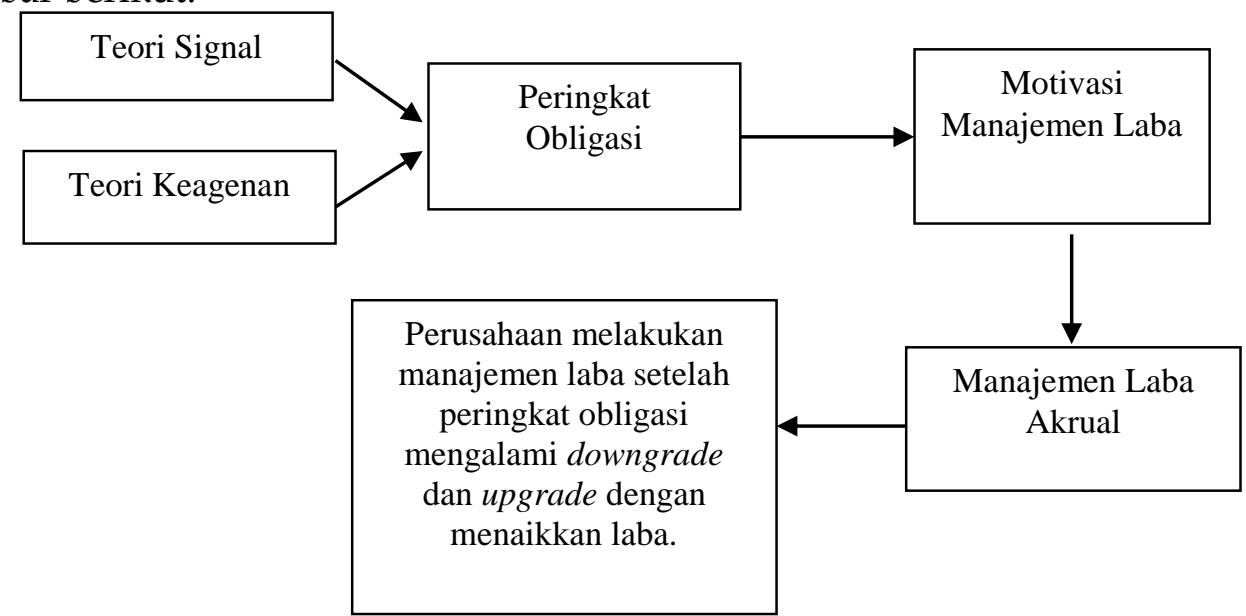

Sumber: Data Penelitian, 2019

\section{Gambar 1. Desain Penelitian}

Penelitian mengambil perusahaan non keuangan yang terdartar di Bursa Efek Indonesia pada periode 2010-2016 melalui laman www.idx.co.id dan www.PEFINDO.com.

Penelitian ini mengacu pada model Jones (1991) untuk menghitung discretionary accruals dengan langkah berikut. Pertama, nilai total accruals ditentukan dengan mengkategorikan antara discretionary accruals dengan nondiscretionary accrual dengan rumus berikut.

$$
\mathrm{TA}=\mathrm{NDA}+\mathrm{DA}
$$

lakukan penghitungan total accrual berikut.

$$
\mathrm{TA}=\mathrm{NI}-\mathrm{CFO}
$$

Nilai non-discretionary accrual kemudian dihitung melalui cara berikut.

$$
N A_{i t}=a_{1}\left(1 / A_{i t-1}\right)+a_{2}\left(\Delta \operatorname{Rev}_{t} / A_{i t-1}-\Delta \operatorname{Rec}_{t} / A_{i t-1}\right)+a_{3}\left(P P E_{t} / A_{i t-1}\right)
$$

Parameter dalam persamaan (3) diperoleh dari hasil regresi yang menggunakan model Jones (1991), yaitu:

$$
T A_{i t}-/ A_{i t-1}=a_{1}\left(1 / A_{i t-1}\right)+a_{2}\left(\Delta \operatorname{Rev}_{t} / A_{i t-1}\right)+a_{3}\left(P_{P E} / A_{i t-1}\right)+\square_{i t}
$$

Dalam persamaan (4) terlihat bahwa nilai discretionary accruals merupakan nilai residu (error term) dari regresi, dan untuk menghitung nilai discretionary accruals dilakukan dengan rumus:

$D A_{i t}=T A_{i t}-/ A_{i t-1}-\left[a_{1}\left(1 / A_{i t-1}\right)+a_{2}\left(\Delta \operatorname{Rev}_{t} / A_{i t-1}-\Delta \operatorname{Rec}_{t} / A_{i t-1}\right)+a_{3}\left(P P E t / A_{i t-1}\right] \ldots\right.$ (5)

Dimana:

TA : Total accruals dalam periode $t$

NDA : Non-discretionary accruals dalam periode $\mathrm{t}$

DA : Discretionary accruals dalam periode $\mathrm{t}$

A : Total assets periode $\mathrm{t}-1$

$\Delta$ Rev $\quad$ : Perubahan penjualan bersih dalam periode $t$

$\Delta$ Rec $\quad$ : Perubahan piutang bersih dalam periode $t$ 
PPE : Property, Plan and Equipment dalam periode $\mathrm{t}$

$\mathrm{a}_{1}, \mathrm{a}_{2}, \mathrm{a}_{3}$ : Parameter yang diperoleh dari regresi persamaan (4)

Penelitian ini menggunakan perusahaan nonkeuangan yang menerbitkan obligasi dan terdaftar pada BEI selama tahun 2010-2016 serta mengalami upgrade dan downgrade peringkat obligasi seperti yang dilaporkan oleh lembaga pemeringkat obligasi PEFINDO. Sampel diambil dengan menggunakan metode purposive sampling, dengan kriteria diantaranya perusahaan bergerak di bidnag non keuangan, perusahaan mengalamai upgrade dan downgrade seperti yang telah diperingkat oleh PEFINDO periode 2010-2016, memiliki laporan audit lengkap dan terdaftar di BEI. Data dikumpulkan melalui metode observasi nonpartisipan, yakni peneliti memperoleh data melalui bacaan literatur, data-data, dan meninjau dengan cermat melalui lama website yang dibutuhkan. Teknik analisis data dilakukan dengan analisis statistik deskriptif, uji normalitas, serta uji hipotesis.

Alat uji hipotesis yang digunakan dalam penelitian yakni, uji One Sample T-Test. Pengujian dilakukan setelah persyaratan uji, yakni data berdistribusi normal. Kriteria dalam pengambilan keputusan ini sebagai berikut: Jika nilai Sig. (2-tailed) $>$ a $(0,05)$, maka $\mathrm{H}_{0}$ diterima, artinya perusahaan melakukan manajemen laba setelah perubahan peringkat obligasi dengan menurunkan laba (income decreasing). Jika nilai Sig, (2-tailed) $\leq$ a $(0,05)$, maka $\mathrm{H}_{0}$ ditolak, artinya perusahaan melakukan manajemen laba setelah perubahan peringkat obligasi dengan menaikkan laba (income increasing).

\section{HASIL DAN PEMBAHASAN}

Penelitian dengan menentukan perusahaan nonkeuangan yang memenuhi syarat penentuan sampel dengan hasil sebagai berikut dengan rincian sebagai berikut.

\section{Tabel 2. Hasil Seleksi Pemilihan Sampel}

\begin{tabular}{clc}
\hline No. & Keterangan & Jumlah \\
\hline 1 & Perusahaan non keuangan yang menerbitkan obligasi & 190 \\
2 & Perusahaan yang peringkat obligasi tetap & $(149)$ \\
3 & Perusahaan yang tidak terdaftar di BEI & $(11)$ \\
4 & Jumlah sampel penelitian & 30 \\
\hline
\end{tabular}

Sumber: PEFINDO, 2019

Perusahaan yang sesuai dengan kriteria sampel yang telah ditentukan sebelumnya adalah berjumlah 30 perusahaan, sehingga penelitian ini menggunakan sampel 30 perusahaan.

Statistik deskriptif menentukan gambaran mengenai data dari penelitian yang diambil, dalam hal ini terkait discretionary accruals (DA) peringkat obligasi perusahaan yang mengalami upgrade dan downgrade. Hasil pengujian statistik deskriptif disajikan pada tabel 2 berikut.

Tabel 3. Hasil Uji Statistik Deskriptif

\begin{tabular}{llllll}
\hline & $\mathrm{N}$ & Minimum & Maximum & Mean & Std. Deviation \\
\hline DA_SETELAH & 30 & -0.179 & 0.123 & 0.02954 & 0.070718 \\
\hline
\end{tabular}

Sumber: Data Penelitian 2019

Tabel 3 menunjukkan bahwa DA perusahaan memiliki standar deviasi sebesar 0,070718. Hal ini memperlihatkan besar peningkatan maksimum rata- 
rata DA perusahaan setelah mengalami upgrade adalah +0.070718 , sedangkan penurunan maksimum dari rata-ratanya adalah -0.070718 .

Uji persyaratan yang dilakukan untuk menguji hipotesis dengan uji $\mathrm{T}$ adalah uji normalitas residual yang hendaknya berdistribusi normal. Kenormalitasan data diuji dengan kolmogorov-Smirnov Test dengan taraf signifikansi sebesar 5\% (0.05). Hasil uji normalitas pada manajemen laba yang diproksikan dengan akrual diskresioner (DA) disajikan dalam Tabel 3. berikut ini.

Tabel 4. Hasil Uji Normalitas

\begin{tabular}{ccccc}
\hline No & Variabel & $\mathrm{N}$ & $\begin{array}{c}\text { Taraf } \\
\text { Signifikansi }\end{array}$ & $\begin{array}{c}\text { Asimp. Sig. } \\
\text { (2-tailed) }\end{array}$ \\
\hline 1 & DA setelah & 30 & 0.05 & 0.552 \\
\hline
\end{tabular}

Sumber: Data Penelitian, 2019

Berdasarkan Tabel 4 menunjukkan bahwa data DA perusahaan setelah mengalami perubahan peringkat obligasi baik upgrade maupun downgrade memiliki nilai yang lebih besar dari taraf signifikansi (0.05) yaitu sebesar 0.552 sehingga dapat disimpulkan bahwa data DA perusahaan setelah mengalami perubahan peringkat obligasi baik upgrade maupun downgrade memiliki distribusi yang normal. Pengujian hipotesis dengan One Sample T-Test dapat dilanjutkan karena persyaratan uji telah terpenuhi.

Data penelitian yang telah lolos kriteria dan berdistribusi normal dapat dilanjutkan dengan melakukan uji hipotesis menggunakan One Sample T-Test setelah persyaratan terpenuhi dan dinyatakan berdistribusi normal. Uji One Sample T-Test memberikan perbandingan antara discretionary accruals positif dengan discretionary accruals negatif. Hasil pengujian One Sample T-Test disajikan pada Tabel 5 berikut.

Tabel 5. One Sample T-Test

\begin{tabular}{|c|c|c|c|c|c|c|}
\hline & \multicolumn{6}{|c|}{ Test Value $=0$} \\
\hline & \multirow[t]{2}{*}{$\mathrm{T}$} & \multirow{2}{*}{ Df } & \multirow{2}{*}{$\begin{array}{l}\text { Sig. } \\
\text { tailed) }\end{array}$} & \multirow{2}{*}{$\begin{array}{l}\text { (2- Mean } \\
\quad \text { Difference }\end{array}$} & \multicolumn{2}{|c|}{$\begin{array}{l}95 \% \text { Confidence Interval of } \\
\text { the Difference }\end{array}$} \\
\hline & & & & & Lower & Upper \\
\hline DA_SETELAH & 2.288 & 29 & 0.030 & 0.029539 & 0.00313 & 0.05595 \\
\hline
\end{tabular}

Sumber: Data Penelitian, 2019

Tabel tersebut menunjukkan nilai sig. (2-tailed) variabel discretionary accruals sebesar 0,030 kurang dari 0,05. Hal ini berarti bahwa $\mathrm{H}_{1}$ diterima yaitu manajer perusahaan akan melakukan laba setelah perusahaan mengalami upgrade maupun downgrade dalam peringkat obligasinya dengan cara menaikkan laba. Teori agensi menyebutkan bahwa ada perbedaan kepentingan antara pemiliki dan pengelola perusahaan. Perbedaan inilah yang menyebabkan adanya asimetri informasi, dimana manajer memiliki informasi internal yang tidak dimiliki prinsipal. Informasi ini menyebabkan manajer melakukan praktik manajemen laba dengan tujuan untuk mempertahankan citra perusahaan di mata investor.

Hasil pengujian hipotesis menunjukkan bahwa $\mathrm{H}_{1}$ diterima hal ini berarti bahwa perusahaan melakukan manajemen laba setelah peringkat obligasi mengalami perubahan baik downgrade ataupun upgrade. Praktik manajemen laba 
dilakukan karena adanya perbedaan tujuan informasi antara penerbit obligasi dan investor.

Peringkat obligasi yang meningkat dapat menjadi salah satu sinyal positif bagi investor untuk menanamkan modalnya di perusahaan. Teori sinyal berpendapat bahwa manajer akan memberikan sinyal kepada investor terkait keadaan perusahaan untuk menghindari adanya asimetri informasi. Ketika perusahaan mengalami downgrade, manajer cenderung akan melaksanakan manajemen laba dengan menaikkan laba untuk mempertahankan kepercayaan investor kepada perusahaan, dan penerbit obligasi dapat tetap memperoleh bantuan dana. Hal ini disebabkan karena manajer cenderung untuk bersikap oportunistik dan menghindari risiko (Dewi \& Yasa, 2015).

Katogori non investment grade merupakan kumpulan perusahaan yang dianggap kurang mampu dalam melunasi utang beserta bunganya. Penerbit obligasi dalam kategori ini mengalami kesulitan dalam memperoleh pendanaan. sebaliknya kategori investment grade merupakan kumpulan perusahaan yang dianggap mampu melunasi utang beserta bunganya. Semakin tinggi peringkat suatu obligasi maka semakin mudah untuk memperoleh pendanaan. oleh sebab itu perusahaan termotivasi dalam melakukan manajemen laba untuk memberikan suatu sinyal positif kepada investor.

Hasil penelitian ini sejalan dengan penelitian Wahyudi, (2014) yaitu manajemen laba yang dilakukan oleh manajer memiliki pengaruh positif pada peringkat obligasi. Sejalan dengan penelitian Oktaviyani, (2013) bahwa peringkat obligasi dipengaruhi secara positif oleh manajemen laba.

\section{SIMPULAN}

Obligasi merupakan salah satu instrumen pasar modal yang banyak digemari para investor. Hal ini karena obligasi menawarkan beberapa keuntungan, seperti hak klaim pertama atas aset perusahaan, memperoleh bunga, dan keuntungan lainnya. Investor sebelum mengambil keputusan investasi membutuhkan informasi yang cukup untuk menentukan perusahaan mana yang akan dijadikan tempat menanamkan modalnya. Oleh karena itu, peringkat obligasi yang diterbitkan oleh lembaga pemeringkat menjadi sangat penting. Peringkat obligasi menunjukkan perusahaan yang memiliki kemampuan dalam memenuhi kewajibannya. Perusahaan yang mengalami upgrade, berada pada peringkat tinggi dalam obligasi dan menunjukkan bahwa perusahaan dalam keadaan baik dan layak untuk diinvestasikan. Namun sebaliknya, perusahaan yang mengalami downgrade berarti memiliki kesulitan dalam memenuhi tanggungjawab utangnya. Manajer merespon peringkat obligasi dengan melakukan praktik manajemen laba. Hal ini dilakukan guna mempertahankan posisi perusahaan dan mencegah likuidasi perusahaan dengan menaikkan laba, dimana salah satu metode yang sering digunakan adalah discretionary accruals. Tujuannya adalah agar perusahaan tidak sampai berada pada posisi non investment grade atau posisi tidak layak untuk diinvestasikan. Penelitian untuk menunjukkan bahwa manajemen laba memberikan pengaruh positif pada peringkat obligasi.

Berdasarkan uraian simpulan diatas, saran yang dapat peneliti sampaikan sebagai berikut: Manajemen perusahaan disarankan untuk lebih 
berhati-hati dalam mengambil keputusan terkait melakukan manajemen laba atau tidak, karena hal ini berdampak dalam pemberian peringkat obligasi serta sikap investor dalam merespon tindakan manajemen laba. Penelitian ini masih terdapat kelemahan yakni jumlah sampel yang terbatas. Oleh karetan itu peneliti selanjutnya disarankan menguji manajemen laba pada perusahaan yang mengalami perubahan peringkat obligasi yang diperingkat oleh seluruh lembaga pemeringkatan yang diakui di Indonesia, kemudian membadingkan antar lembaga pemeringkat. Kelemahan lain dari penelitian ini tidak melakukan penggolongan perusahaan berdasarkan sektor-sektor. Oleh karena itu peneliti selanjutnya dapat mengelompokkannya dalam sektor-sektor . Kemudian hasilnya dibandingkan untuk mengetahui sektor mana yang paling agresif melakukan manajemen laba setelah perubahan peringkat obligasi.

\section{REFERENSI}

Ade, J. F. (2004). Analisis Pengaruh Penurunan/Perolehan Peringkat Obligasi Perusahaan ke dalam Kategori Non-Investment Grade Terhadap Praktik Manajemen Laba. Makalah Simposium Nasional Akuntansi VII Denpasar, 11021121.

Andriyani, C., \& Darmawati, D. (2016). Pengaruh Manajemen Laba, Jaminan dan Umur Obligasi terhadap Peringkat Obligasi. In Seminar Nasional Cendekiawan (pp. 1-13).

Bouwens, V. (2017). Credit Ratings and Earnings Management in the European Market. Accounting and Auditing/Control Erasmus University Rotterdam.

Cooke, C., \& Bailey, F. (2015). The Impact of Credit Rating Changes on Jamaica's Global Bond Prices (Vol. 13).

Dewi, M. K., \& Yasa, G. W. (2015). Manajemen Laba Setelah Penurunan Peringkat Obligasi Perusahaan. E-Jurnal Akuntansi Universitas Udayana, 12(2), 280-294.

Ederington, L., Guan, W., \& Yang, L. (2015). Bond market event study methods. Journal of Banking and Finance, 58(December 2017), 281-293. https:// doi.org/10.1016/j.jbankfin.2015.03.013

Elkhoury, M. (2009). Credit Rating Agencies and Their Potential Impact on Developing Countries. Compendium on Debt Sustainability and Development, 1(186), 165-190. Retrieved from http:/ / unctad.org/en/docs/gdsddf20081_en.pdf\#page $=170$

Ge, W., \& Kim, J. B. (2014). Real earnings management and the cost of new corporate bonds. Journal of Business Research, 67(4), 641-647. https:// doi.org/10.1016/j.jbusres.2013.01.021

Haryono, Y. ST., \& Prodi. (2015). Dampak Pengumuman Peringkat Obligasi Pada Kinerja Obligasi Di Bursa Efek Indonesia Dan Pt Pefindo. Jurnal Keuangan Dan Perbankan, 19(1), 41-51.

Jorion, P., \& Zhang, G. (2009). Information Effects of Bond Rating Changes. The Journal of Fixed Income, 16(4), 45-59. https:/ / doi.org/10.3905/jfi.2007.683317

Mahfudhoh, R. U., \& Cahyonowati, N. (2014). Analisis Faktor-Faktor yang Mempengaruhi Peringkat Obligasi. Diponegoro Journal of Accounting, 1(1), 113.

Markopou, M. K., \& L, P. D. (2009). Capital Structure Signaling Theory : Evidence 
From the Greek Stock Exchange. Portuguese Journal of Management Studies, XIV(3), 217-238.

Michayluk, D., \& Zhao, R. (2010). Stock splits and bond yields: Isolating the signaling hypothesis. Financial Review, 45(2), 375-386. https://doi.org/10.1111/j.1540-6288.2010.00252.x

Naser, K., Al-Mutairi, A., Kandari, A. Al, \& Nuseibeh, R. (2015). Cogency of Capital Structure Theories to an Islamic Country: Empirical Evidence from the Kuwaiti Banks. International Journal of Economics and Financial Issues, 5(4), 979-988. Retrieved from http:\%0Awww.econjournals.com

Oktaviyani, R. D. (2013). Pengaruh Manajemen Laba, Rasio Keuangan dan Mekanisme Corporate Governance terhadap Peringkat Obligasi. Skripsi. Sarjana Ekonomi Fakultas Ekonomi Universitas Negeri Semarang.

Parnes, D., \& Akron, S. (2016). Rating The Credit Rating Agencies. Journal of Applied Economics, 48(50), 4799-4812.

Partha, I. M. B., \& Yasa, G. W. (2016). Kemampuan Rasio Keuangan dalam Memprediksi Peringkat Obligasi pada Perusahaan Sektor Non Keuangan. EJurnal Akuntansi Universitas Udayana, 15(3), 1913-1941.

Payne, J. (2014). The Role of Gatekeepers. Oxford Handbook of Financial Regulation, 2(22), 1-27. https:// doi.org/10.2139/ssrn.2428121

Prakash, S., Ayachit, A., \& Garg, S. (2017). Regulation of Credit Rating Agencies in India. India. Retrieved from https://static1.squarespace.com/static/551ea026e4b0adba21a8f9df/t/597f2 62915d5dbc171f504fb/1501505083636/170731_CRAReport.pdf

Pratiwi, W. C., Nyoman, D., Werastuti, S., Sujana, E., \& Ganesha, U. P. (2015). Analisis Discretionary Accrual Dalam Merespon Downgrade Obligasi Perusahaan. E-Journal S1 Ak Universitas Pendidikan Ganesha, 3(1).

Rhee, R. J. (2015). Why Credit Rating Agencies Exist. Review of Banking, Finance, and Monetary Economics, 44(2).

Sari, I. K., \& Yasa, G. W. (2016). Pengaruh Penerapan Good Corporate Governance, Profitabilitas, dan Likuiditas terhadap Peringkat Obligasi. EJurnal Akuntansi Universitas Udayana, 17(3), 2198-2224.

Scott, W. R. (2015). Financial Accounting Theory. (Prentice-hall, Ed.) (7th ed.). USA.

Shin, M.-S., Kim, S.-E., \& Shin, J.-H. (2012). The Effects of Credit Ratings on Capital Structure: Evidence from Korea. Journal of Finance and Accountancy, 11, 12-28. Retrieved from http://www.aabri.com/copyright.html.\%0Ahttp://www.aabri.com/manu scripts/121139.pdf

Wahyudi, T. (2014). Pengaruh Manajemen Laba Terhadap Peringkat Obligasi Pada Saat Emisi. Jurnal Manajemen, Akuntansi, Dan Enterpreneur, 3(2).

Wicaksono, A. (2015). Pengaruh Asimetri Informasi Terhadap Manajemen Laba Melalui Manipulasi Aktivitas Riil. Jurnal Riset Ekonomi Dan Manajemen, 15(1), 84. https:// doi.org/10.17970/jrem.15.150107.id

Yasa, G. W. (2010). Pemeringkatan Obligasi Perdana Sebagai Pemicu Manajemen Laba: Bukti Empiris Dari Pasar Modal Indonesia. In Simposium Nasional Akuntansi XIII (pp. 1-30). 